\title{
PENGETAHUAN, SIKAP, DAN PRAKTIK MENGENAI HIGIENE PERSONAL SEBAGAI UPAYA PENCEGAHAN COVID-19 DI PROVINSI DKI JAKARTA
}

\author{
Kamila Nandita Zuriyanda ${ }^{1^{*}}$; Yusniar Hanani Darundiati ${ }^{2}$; Sulistiyani Sulistiyani ${ }^{2}$ \\ ${ }_{1}^{1}$ Peminatan Kesehatan Lingkungan, Fakultas Kesehatan Masyarakat Universitas Diponegoro \\ ${ }^{2}$ Bagian Kesehatan Lingkungan, Fakultas Kesehatan Masyarakat Universitas Diponegoro \\ ${ }^{*}$ Corresponding author: kamilanz11@gmail.com
}

\begin{abstract}
ABSTRAK
COVID-19 is disease caused by SARS-CoV2 and becoming world concern because large number of cases and fast transmission between humans. Therefore, it is needed of knowledge, attitude, and practice of personal hygiene as primary pervention during COVID-19 pandemic. The purpose of this research is to find out the knowledge, attitude, and practice of personal hygiene as COVID-19 pervention in DKI Jakarta. This was descriptive research with cross-sectional study design. The data research was using googleform online questionnaire. Sample of this research are 150 respondents aged 15-29 years old in DKI Jakarta during COVID-19 pandemic. Data analysis using univariate and bivariate (chi square). Based on the research results, it was found that the majority of respondents had $51.3 \%$ moderate knowledge, 56\% moderate attitudes, $84.7 \%$ moderate practice, and there was significant relationship between knowledge and attitudes $(p$-value $=0,04)$ but there is no significant relationship between attitude and practice $(p$-value $=0.086$ ). It can be concluded that respondents already have moderate knowledge, attitudes, and practices regarding personal hygiene in the prevention of COVID-19. It's hoped that the public will always follow the development of information regarding the prevention of COVID-19, especially regarding hand hygiene, the ethics of coughing or sneezing and practicing it in everyday life.
\end{abstract}

Keywords: COVID-19; personal hygiene; knowledge; attitude; practice

\section{PENDAHULUAN}

COVID-19

merupakan penyakit disebabkan oleh SARS-CoV2 dan diumumkan sebagai pandemi oleh WHO. ${ }^{1}$ COVID-19 menjadi perhatian dunia karena banyaknya jumlah kasus dan transmisi cepat antar manusia. ${ }^{2}$ Berdasarkan laporan WHO tanggal 16 Desember 2020, kasus COVID-19 di Indonesia mencapai 629.429 kasus positif, 19.111 kasus kematian, dan klasifikasi penyebaran melalui komunitas. ${ }^{3}$ Penyebaran COVID-19 terjadi melalui droplet batuk atau bersin yang terhirup atau menempel pada tubuh manusia. ${ }^{4}$ Berdasarkan situs nasional COVID-19 tanggal 16 Desember 2020, kasus COVID-19 terbanyak di Indonesia terjadi di Provinsi DKI Jakarta dengan 156.343 kasus positif. ${ }^{5}$

Kasus asimtomatik COVID-19 mempersulit perkiraan penyebaran dan penyusunan strategi mengatasi COVID-19.1, Kasus asimtomatik di China ditermukan pada usia 5-95 tahun, namun sedikit ditemukan di bawah usia 15 tahun. Selain itu di luar Kota Wuhan, China ditemukan penularan COVID-19 tanpa gejala pada umur 16-23 tahun. Sedangkan pada umur 30-60 tahun di Wuhan, China umumnya memperlihatkan gejala COVID-19. ${ }^{6}$ Maka kasus asimtomatik berisiko pada rentang umur di atas 15 tahun dan dibawah 30 tahun.

Indonesia memberlakukan panduan strategis untuk penanganan COVID-19 dari Gugus Tugas Percepatan Penanganan COVID-19 mulai dari tingkat individu hingga masyarakat. ${ }^{7}$ Higiene personal merupakan salah satu pencegahan dasar tingkat individu untuk menjaga kebersihan dan kesehatan diri khususnya untuk menghindari risiko infeksi COVID-19.8 Higiene personal membantu menghindari infeksi dan penyebaran penyakit pernapasan melalui droplet yang menempel pada tubuh manusia. Penting untuk mempunyai dasar mengenai higiene personal sehingga dapat dipraktikkan pada kehidupan sehari hari.

Selain itu higiene personal juga penting untuk didasari dengan pengetahuan, sikap, dan praktik masyarakat selama pandemi COVID-19 untuk memahami dinamika epidemiolgi COVID-19, kepatuhan, dan keberhasilan suatu negara dalam mencegah dan mengontrol COVID-19. ${ }^{9}$ Oleh karena itu penelitian ini bertujuan untuk mengentahui pengetahuan, 


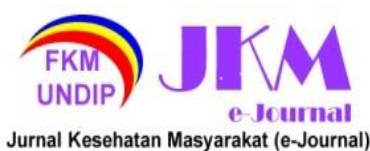

sikap, dan perilaku higiene personal masyarakat Provinsi DKI Jakarta.

\section{METODE PENELITIAN}

Penelitian ini merupakan penelitian deskriptif dengan desain cross-sectional. Pengambilan data penelitian menggunakan metode survei dengan penyebaran angket online berupa link googleform berisi kriteria sampel dan angket yang diunggah pada media sosial. Variabel yang diteliti adalah jenis kelamin, tingkat pendapatan, pendidikan terakhir, dan status bekerja, pengetahuan higiene personal, sikap higiene personal, praktik higiene personal selama pandemi COVID-19.

Populasi penelitian yaitu 2.405 .406 individu berusia $15-29$ tahun di Provinsi DKI karena pada umur tersebut mempunyai mobilisasi yang tinggi dan banyaknya jumlah kasus pada rentang umur tersebut. Sampel diambil menggunakan consecutive sampling yang disesuaikan dengan kriteria sampel sebesar 150 responden dengan kriteria berusia 15-29 tahun, bertempat tinggal, dan berdomisili di Provinsi DKI Jakarta selama pandemi COVID-19.

Data pengetahuan higiene personal, sikap higiene personal, dan praktik higiene personal dikategorikan menjadi tiga kategori yaitu kurang, cukup, dan baik menggunakan mean dan standar deviasi karena data berdistribusi normal. Data penelitian dianalisis menggunakan analisis univariat dengan penyajian distribusi frekuensi seluruh variabel yang diteliti dan analisis bivariat dengan chi square untuk melihat hubungan antar variabel pengetahuan higiene personal, sikap higiene personal, dan praktik higiene personal.

\section{HASIL DAN PEMBAHASAN}

\section{Gambaran Umum Provinsi DKI Jakarta}

Provinsi DKI Jakarta merupakan salah satu dari 34 provinsi di Indonesia. ${ }^{10}$ Provinsi DKI Jakarta terdiri dari 6 kabupaten/kota yaitu Jakarta Selatan, Jakarta Timur, Jakarta Pusat, Jakarta Barat, Jakarta Utara, dan Kepulauan Seribu. ${ }^{11}$

Berikut merupakan tabel distribusi frekuensi karakteristik responden.

Tabel 1. Distribusi Frekuensi Karakteristik Responden di Provinsi DKI Jakarta tahun 2020

\begin{tabular}{lll}
\hline \multicolumn{1}{c}{ Variabel } & $\mathbf{n}$ & $\%$ \\
\hline $\begin{array}{l}\text { Jenis Kelamin }(\mathbf{n}=150) \\
\text { Laki-laki }\end{array}$ & 34 & 22,7
\end{tabular}

\begin{tabular}{|c|c|c|}
\hline Perempuan & 116 & 77,3 \\
\hline \multicolumn{3}{|c|}{ Pendidikan Terakhir $(n=150)$} \\
\hline Tamat SMP/sederajat & 22 & 14,7 \\
\hline Tamat SMA/sederajat & 85 & 56,7 \\
\hline Tamat perguruan tinggi & 43 & 28,7 \\
\hline \multicolumn{3}{|l|}{ Status Bekerja $(n=150)$} \\
\hline Belum bekerja & 113 & 75,3 \\
\hline Sudah bekerja & 37 & 24,7 \\
\hline \multicolumn{3}{|c|}{ Tingkat pendapatan $(n=37)$} \\
\hline $\begin{array}{l}\text { Kurang } \\
(<\text { Rp4.276.349,906) }\end{array}$ & 9 & 24,3 \\
\hline $\begin{array}{l}\text { Cukup } \\
(\geq \operatorname{Rp} 4 \cdot 276 \cdot 349,906)\end{array}$ & 28 & 75,7 \\
\hline
\end{tabular}

Tabel 1 menunjukkan sebagian besar responden berjenis kelamin perempuan sebanyak 116 responden (77,3\%), berpendidikan terakhir tamat SMA/sederajat sebanyak 85 responden $(56,7 \%)$, berstatus belum bekerja sebanyak 113 responden (75,3\%), dan tingkat pendapatan cukup di atas upah minimum Provinsi DKI Jakarta sebanyak 28 responden $(75,7 \%)$ sudah bekerja.

Gambaran Pengetahuan, Sikap, dan Praktik Higiene Personal Responden selama Pandemi COVID-19 tahun 2020

Tabel 2. Distribusi Frekuensi Pengetahuan, Sikap, dan Praktik Higiene Personal Responden selama Pandemi COVID-19 tahun 2020

\begin{tabular}{lcc}
\hline \multicolumn{1}{c}{ Variabel } & $\mathbf{n}$ & $\%$ \\
\hline Pengetahuan $(\mathbf{n = 1 5 0 )}$ & & \\
Kurang & 38 & 25,3 \\
Cukup & 77 & 51,3 \\
Baik & 35 & 23,3 \\
\hline Sikap (n=150) & & \\
Kurang & 34 & 22,7 \\
Cukup & 84 & 56 \\
Baik & 32 & 21,3 \\
\hline Praktik (n=150) & & \\
Kurang & 16 & 10,7 \\
Cukup & 127 & 84,7 \\
Baik & 7 & 4,7 \\
\hline
\end{tabular}

Sumber : Data Primer, 2020

Tabel 2 menunjukkan pengetahuan, sikap, dan praktik higiene personal responden selama pandemi COVID-19 terbanyak tergolong cukup sebesar 77 responden $(51,3 \%), 84$ responden (56\%), dan 127 responden $(84,7 \%)$. 


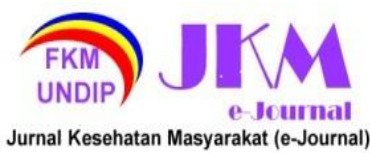

\section{Pengetahuan}

Hasil penelitian menunjukkan 51,3\% responden mempunyai pengetahuan cukup mengenai higiene personal selama pandemi COVID-19. Pengetahuan seseorang dapat mempengaruhi perilaku sebagai dasar untuk bertindak. ${ }^{6}$

Pengetahuan mengenai bagian tubuh yang penting dijaga higiene personalnya selama pandemi COVID-19 terbanyak dijawab dengan benar oleh $86 \%$ responden. Mata, tangan, hidung, dan mulut merupakan bagian tubuh yang penting dijaga higiene personalnya selama pandemi COVID-19 karena penyebaran virus mudah terjadi akibat droplet yang masuk melalui bagian tubuh tersebut. ${ }^{12}$

Pengetahuan mengenai etika batuk dan bersin, sebanyak $80 \%$ responden memilih jawaban yang salah. Berdasarkan Pedoman Penanganan Cepat Medis dan Kesehatan Masyarakat COVID-19, etika batuk dan bersin yang tepat ialah menutup hidung atau mulut menggunakan lengan atas atau tisu, namun masih banyak responden yang memilih menggunakan telapak tangan. ${ }^{7}$ Telapak tangan untuk menutupi hidung atau mulut saat bersin dan batuk tidak dianjurkan agar permukaan tangan yang terinfeksi tidak menyentuh mata, hidung, dan mulut. ${ }^{13}$

Masih terdapat responden yang menjawab pertanyaan dengan jawaban yang salah mungkin terjadi akibat banyak penyebaran informasi yang tidak akurat mengenai COVID-19 di Indonesia. Hal tersebut dibahas Nasir dkk dalam penelitian mengenai penyebaran informasi COVID-19 di Indonesia. Penyebaran informasi COVID-19 yang tidak akurat di Indonesia umumnya mengenai fakta dasar, transmisi, hingga pencegahan COVID-19. Informasi tersebut menyebar secara masif di media social. ${ }^{14} \mathrm{Hal}$ tersebut sesuai dengan penelitian ini karena sampel penelitian ini merupakan pengguna aktif media sosial.

Diharapkan responden dapat mencerna informasi dan mencari sumber informasi terpercaya seperti WHO atau Kementerian Kesehatan Indonesia mengenai COVID-19 dan pencegahannya yaitu khususnya higiene personal mengenai etika batuk atau bersin yang benar agar pengetahuan responden menjadi baik.

\section{Sikap}

Hasil penelitian menunjukkan 56\% responden menyikapi higiene personal sebagai upaya pencegahan COVID-19 dengan cukup. Sikap tersebut berupa keyakinan setuju atau tidak setujunya responden mengenai higiene personal selama pandemi COVID-19.

Responden sebanyak $88,7 \%$ menyikapi sangat setuju higiene personal merupakan upaya dasar pencegahan COVID-19. Higiene personal merupakan pencegahan tingkat primer untuk mengurangi mikroorganisme asing masuk ke dalam tubuh manusia. ${ }^{15}$ Oleh karena itu higiene personal dapat dijadikan upaya pencegahan penyakit di antaranya COVID-19.8 Hasil penelitian ini sejalan dengan penelitian Gudi et al yaitu $93,6 \%$ responden setuju dengan menjaga higiene personal dapat mencegah penyebaran COVID-19. ${ }^{16}$

Menurut WHO, diperlukan fokus higiene personal terutama kebersihan tangan (Kementerian Kesehatan Republik Indonesia, 2020). Sebanyak 64,7\% responden menyikapi sangat setuju bahwa mencuci tangan sebelum dan sesudah beraktivitas akan menghindarkan dari COVID-19 sesuai dengan Water, Sanitation, Hygiene and Waste Management for the COVID-19 Virus yaitu mencuci tangan dilakukan sesering mungkin untuk membantu mencegah penularan atau infeksi virus COVID-19 yang ditularkan melalui tangan. ${ }^{13}$ Mencuci tangan sebelum dan sesudah beraktivitas merupakan kewajiban untuk menghindari kontak dengan sumber yang berpotensi menularkan COVID-19. ${ }^{17}$

Responden sebanyak $7,3 \%$ menyikapi sangat setuju menutup hidung atau mulut dapat menggunakan telapak tangan saat bersin atau batuk. Hal tersebut tidak sesuai dengan Pedoman Penanganan Cepat Medis dan Kesehatan Masyarakat COVID-19 di Indonesia yaitu jika batuk dan bersin dianjurkan untuk menutup mulut dan hidung menggunakan lengan atas atau tisu. ${ }^{7}$ Etika bersin dan batuk yang tepat tidak menggunakan telapak tangan agar menghindari permukaan tangan yang terinfeksi menyentuh mata, hidung, dan mulut. ${ }^{13}$

Pada penelitian Reuben et al, sikap responden pada penelitian tersebut digolongkan sangat baik dengan 94,7\% 


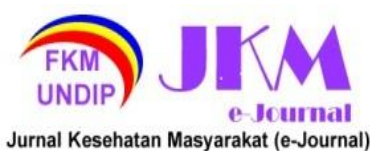

responden sudah menyadari isi pedoman preventif COVID-19 dari pemerintah setempat yang di antaranya mengenai higiene personal. ${ }^{9}$ Penelitian tersebut bertolak belakang dengan penelitian ini yaitu persentase terbesar sikap higiene personal dalam upaya pencegahan COVID-19 sesuai pedoman preventif COVID-19 yang berlaku hanya tergolong cukup sebanyak $56 \%$ responden. Perlu dilakukan perubahan sikap terutama mengenai etika bersin atau batuk yang tepat dan kebersihan tangan.

Berdasarkan penelitian yang dilakukan Purwaningrum dkk, sikap dapat dipengaruhi beberapa faktor dalam pembentukannya di antaranya lembaga pendidikan. ${ }^{18}$ Lembaga pendidikan diharapkan dapat menjadi sarana penyalur informasi dengan memberikan pembelajaran terkait awareness mengenai COVID-19 dan upaya pencegahannya karena responden penelitian ini umumnya masih diusia sekolah.

\section{Praktik}

Hasil penelitian menunjukkan 56\% responden menyikapi higiene personal sebagai upaya pencegahan COVID-19 dengan cukup. Sikap tersebut berupa keyakinan setuju atau tidak setujunya responden mengenai higiene personal selama pandemi COVID-19.

Responden sebanyak $\quad 88,7 \%$ menyikapi sangat setuju higiene personal merupakan upaya dasar pencegahan COVID-19. Higiene personal merupakan pencegahan tingkat primer untuk mengurangi mikroorganisme asing masuk ke dalam tubuh manusia. ${ }^{15}$ Oleh karena itu higiene personal dapat dijadikan upaya pencegahan penyakit di antaranya COVID-19. ${ }^{8}$ Hasil penelitian ini sejalan dengan penelitian Gudi et al yaitu 93,6\% responden setuju dengan menjaga higiene personal dapat mencegah penyebaran COVID-19. ${ }^{16}$

Menurut WHO, diperlukan fokus higiene personal terutama kebersihan tangan. ${ }^{13}$ Sebanyak $64,7 \%$ responden menyikapi sangat setuju bahwa mencuci tangan sebelum dan sesudah beraktivitas akan menghindarkan dari COVID-19 sesuai dengan Water, Sanitation, Hygiene and Waste Management for the COVID-19 Virus yaitu mencuci tangan dilakukan sesering mungkin untuk membantu mencegah penularan atau infeksi virus
COVID-19 yang ditularkan melalui tangan. ${ }^{13}$ Mencuci tangan sebelum dan sesudah beraktivitas merupakan kewajiban untuk menghindari kontak dengan sumber yang berpotensi menularkan COVID-19. ${ }^{17}$

Responden sebanyak $7,3 \%$ menyikapi sangat setuju menutup hidung atau mulut dapat menggunakan telapak tangan saat bersin atau batuk. Hal tersebut tidak sesuai dengan Pedoman Penanganan Cepat Medis dan Kesehatan Masyarakat COVID-19 di Indonesia yaitu jika batuk dan bersin dianjurkan untuk menutup mulut dan hidung menggunakan lengan atas atau tisu. ${ }^{7}$ Etika bersin dan batuk yang tepat tidak menggunakan telapak tangan agar menghindari permukaan tangan yang terinfeksi menyentuh mata, hidung, dan mulut. ${ }^{13}$

Pada penelitian Reuben et al, sikap responden pada penelitian tersebut digolongkan sangat baik dengan 94,7\% responden sudah menyadari isi pedoman preventif COVID-19 dari pemerintah setempat yang di antaranya mengenai higiene personal. ${ }^{9}$ Penelitian tersebut bertolak belakang dengan penelitian ini yaitu persentase terbesar sikap higiene personal dalam upaya pencegahan COVID-19 sesuai pedoman preventif COVID-19 yang berlaku hanya tergolong cukup sebanyak $56 \%$ responden. Perlu dilakukan perubahan sikap terutama mengenai etika bersin atau batuk yang tepat dan kebersihan tangan.

Berdasarkan penelitian yang dilakukan Purwaningrum dkk, sikap dapat dipengaruhi beberapa faktor dalam pembentukannya di antaranya lembaga pendidikan. ${ }^{18}$ Lembaga pendidikan diharapkan dapat menjadi sarana penyalur informasi dengan memberikan pembelajaran terkait awareness mengenai COVID-19 dan upaya pencegahannya karena responden penelitian ini umumnya masih diusia sekolah.

Hubungan Pengetahuan, Sikap, dan Praktik Higiene Personal Responden selama Pandemi COVID-19 tahun 2020

Tabel 3. Hubungan Pengetahuan dan Sikap Responden selama Pandemi COVID-19 tahun 2020 


\begin{tabular}{|c|c|c|c|c|c|c|c|}
\hline \multirow{3}{*}{$\begin{array}{l}\text { Vari } \\
\text { abel }\end{array}$} & \multicolumn{6}{|c|}{ Sikap } & \multirow{3}{*}{$\begin{array}{c}\mathbf{P} \\
\text { Val } \\
\text { ue }\end{array}$} \\
\hline & \multicolumn{2}{|c|}{ Kurang } & \multicolumn{2}{|c|}{ Cukup } & \multicolumn{2}{|c|}{ Baik } & \\
\hline & $\mathrm{n}$ & $\%$ & $\mathrm{n}$ & $\%$ & $\mathrm{n}$ & $\%$ & \\
\hline \multicolumn{8}{|c|}{ Pengetahuan } \\
\hline $\begin{array}{l}\text { Kuran } \\
\mathrm{g}\end{array}$ & 14 & 9,3 & $\begin{array}{l}2 \\
1\end{array}$ & $\begin{array}{l}1 \\
4\end{array}$ & 3 & 2 & \\
\hline Cukup & 16 & $\begin{array}{c}10 \\
7\end{array}$ & $\begin{array}{l}4 \\
2\end{array}$ & $\begin{array}{l}2 \\
8\end{array}$ & $\begin{array}{l}1 \\
9\end{array}$ & 12,7 & 0,0 \\
\hline Baik & 4 & 2,7 & $\begin{array}{l}2 \\
1\end{array}$ & $\begin{array}{l}1 \\
4\end{array}$ & $\begin{array}{l}1 \\
0\end{array}$ & 6,7 & \\
\hline
\end{tabular}

Tabel 3 menunjukkan persentase terbesar pada responden yang mempunyai pengetahuan cukup dan sikap cukup mengenai higiene personal selama pandemi COVID-19. Berdasarkan analisis data menggunakan chi square, diketahui $\mathrm{p}$-value sebesar 0,04. Jika $p$-value $<0,05$ dapat disimpulkan adanya hubungan yang signifikan antara pengetahuan dengan sikap.

Penelitian ini sejalan dengan penelitian Paul et al., yaitu adanya hubungan antara pengetahuan dan sikap mitigasi COVID-19 oleh responden. ${ }^{19} \mathrm{Hal}$ ini menunjukkan hal sesuai dengan hasil uji univariat penelitian ini yaitu persentase responden terbanyak yang mempunyai pengetahuan cukup juga mempunyai sikap yang cukup. Sikap responden cenderung dipengaruhi oleh pengetahuan higiene personal yang dimiliki.

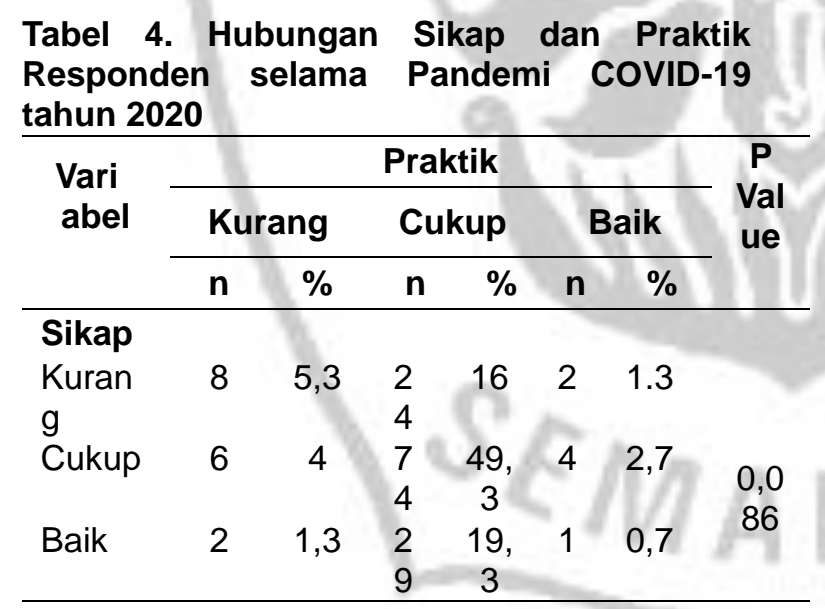

Tabel 4 menunjukkan persentase terbesar pada responden yang mempunyai sikap cukup dan praktik cukup mengenai higiene personal selama pandemi COVID-19. Berdasarkan analisis data menggunakan chi-square, diketahui $p$-value sebesar 0,086. Jika $p$-value > 0,05 dapat disimpulkan tidak adanya hubungan yang signifikan antara sikap dengan praktik.
Pada penelitian yang dilakukan Paul et al., praktik yang dilakukan responden mengenai upaya mitigasi COVID-19 mempunyai hubungan dengan sikap responden terhadap mitigasi COVID-19 tersebut, namun tidak sejalan dengan penelitian ini karena sikap responden tidak mempunyai hubungan dengan praktik. ${ }^{19}$

Sikap belum tentu secara langsung mempengaruhi suatu praktik karena sikap sebagai respons sebuah stimulus akan mempengaruhi praktik secara langsung jika adanya niat atau motivasi yang mendorong untuk melakukan praktik tertentu. ${ }^{20}$

\section{KESIMPULAN}

Pengetahuan, sikap, dan praktik responden mengenai higiene personal selama pandemi COVID-19 digolongkan cukup namun perlu peningkatan pengetahuan etika batuk atau bersin, sikap mencuci tangan dan penggunaan lengan atas atau tisu saat bersin atau batuk, dan praktik mencuci tangan sebelum beraktivitas serta menggunakan sabun dan air mengalir.

\section{SARAN}

Diharapkan masyarakat untuk selalu mengikuti perkembangan informasi mengenai COVID-19 mengenai higiene tangan, etika batuk atau bersin, dan mempraktikannya dalam kehidupan sehari-hari. Peneliti selanjutnya diharapkan dapat menggunakan wawancara terbuka agar gambaran pengetahuan, sikap, dan praktik responden lebih detail dan mendalam.

\section{UCAPAN TERIMA KASIH}

Peneliti berterima kasih kepada seluruh pihak yang membantu kelancaran penelitian dan penulisan artikel penelitian ini di antaranya masyarakat DKI Jakarta, Fakultas Kesehatan Masyarakat Universitas Diponegoro, dan pihak lain yang tidak dapat disebutkan satu persatu oleh peneliti.

\section{DAFTAR PUSTAKA}

1. Bai, Y., Yao, L., Wei, T., Tian, F., Jin, D. Y., Chen, L., \& Wang, M. Presumed Asymptomatic Carrier Transmission of COVID-19. JAMA - Journal of the American Medical Association. American Medical Association. 2020.

2. Wong, J., Goh, Q. Y., Tan, Z., Lie, S. A., Tay, Y. C., Ng, S. Y., \& Soh, C. R. Preparing for a COVID-19 pandemic: a review of operating room outbreak response 


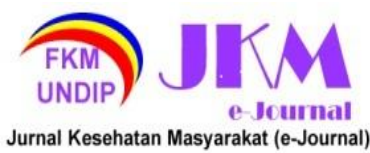

measures in a large tertiary hospital in Singapore. Canadian Journal of Anesthesia. 2020.

3. WHO. WHO Coronavirus Disease (COVID-19) Dashboard December 16th 2020. 2020 [cited 2020 Dec 17] available from: https://covid19. who.int/table

4. Driggin, E., Madhavan, M. V., Bikdeli, B., Chuich, T., Laracy, J., Bondi-Zoccai, G., et al. Cardiovascular Considerations for Patients, Health Care Workers, and Health Systems During the Coronavirus Disease 2019 (COVID-19) Pandemic. Journal of the American College of Cardiology. 2020.

5. Gugus Tugas Percepatan Penanganan COVID-19. Peta Sebaran Kasus COVID-19 Perprovinsi (16 Desember 2020). 2020 [cited 2020 Des 17] available from: https://covid19.go.id/peta-sebaran

6. Wulandari, F., \& Ayu, S. M. Hubungan Tingkat Pengetahuan dan Sikap Dengan Perilaku Pemeriksaan SADARI Mahasiswi. Prosiding Seminar Nasional IKAKESMADA "Peran Tenaga Kesehatan Dalam Pelaksanaan SDGs,". 2017; 1(1), 137-144.

7. Adisasmito, W., Yurianto, A., Pritasari, K., Wibowo, B., Siswanto, Subuh, M., \& Dkk. Pedoman Penanganan Cepat Medis dan Kesehatan Masyarakat COVID-19 di Indonesia. 2020.

8. Handayani, G. L., \& Abbasiah, A. Hubungan Perilaku Kebersihan Perorangan dan Lingkungan Serta Status Gizi dengan Kejadian Infeksi pada Anak Usia Sekolah di Sekolah Dasar Kota Jambi. Jurnal IImiah Universitas Batanghari Jambi. 2020; 20(1), 232.

9. Reuben, R. C., Danladi, M. M. A., Saleh, D. A., \& Ejembi, P. E. Knowledge, Attitudes and Practices Towards COVID-19: An Epidemiological Survey in North-Central Nigeria. Journal of Community Health. 2020; 1-4.

10. Badan Pusat Statistik Indonesia. Statistik Indonesia 2020. 2020.

11. Badan Pusat Statistik Provinsi DKI Jakarta. Provinsi DKI Jakarta dalam Angka 2020. DKI Jakarta. 2020.

12. Rifa, I., Septi Irwansyah, F., Sholihah, A., \& Yuliawati, A. Dampak dan Pencegahan
Wabah Covid-19: Perspektif Sains dan Islam. Jurnal Lembaga Penelitian Dan Pengabdian Masyarakat (LP2M). 2020.

13. Menteri Kesehatan Republik Indonesia Keputusan Menteri Kesehatan Republik Indonesia No.HK.01.07/MenKes/413/2020 tentang Pedoman Pencegahan dan Pengendalian Corona Virus Disease 2019 (COVID-19). DKI Jakarta. 2020.

14. Nasir, N. M., Baequni, B., \& Nurmansyah, M. I. Misinformation Related To Covid-19 in Indonesia. Jurnal Administrasi Kesehatan Indonesia. 2020; 8(2), 51.

15. Fatmawati, T. Y. Pengetahuan Tentang Personal Hygiene Pada Anak Usia Sekolah Di SDN 206 / IV Kota Jambi. Jurnal Akademika Baiturrahim. 2018; 7(1), 10-16

16. Gudi, S. K., Chhabra, M., Undela, K., Venkataraman, R., Mateti, U. V., Tiwari, K. K., \& Nyamagoud, S. Knowledge and beliefs towards universal safety precautions during the coronavirus disease (COVID-19) pandemic among the Indian public: a web-based cross-sectional survey. Drugs and Therapy Perspectives. 2020; 36(9), 413-420.

17. Repici, A., Maselli, R., Colombo, M., Gabbiadini, R., Spadaccini, M., et al. Coronavirus (COVID-19) outbreak: what the department of endoscopy should know. Gastrointestinal Endoscopy. 2020; 92(1), 192-197.

18. Purwaningrum, S. W., Rini, T. S., \& Saurina, N. Hubungan Tingkat Pengetahuan, Sikap dengan Perilaku Warga dalam Pemenuhan Komponen Rumah Sehat. KesMas: Jurnal Fakultas Kesehatan Masyarakat. 2018; 12(1), 5359.

19. Paul, A., Sikdar, D., Hossain, M. M., Amin, M. R., Deeba, F, et al. Knowledge Attitude and Practice Towards Novel Corona Virus among Bangladeshi People Implications for mitigation measures. PLoS ONE. 2020; 15(9), 1-18.

20. Mantiri, H. K., Malonda, N. S. ., \& Rattu, A. J. Hubungan Antara Pengetahuan Sikap Dengan Tindakan Personal Hygiene Pelaku. Kesmas. 2019; 8. 